УДК 697.94.(075)

В.Й. Лабай, Д.І. Гарасим

Національний університет «Львівська політехніка», вул. Ст. Бандери, 12, Львів, 79013

\title{
ДОСЛІДЖЕННЯ ЕКСЕРГЕТИЧНОЇ ЕФЕКТИВНОСТІ СИСТЕМ КОНДИЦІЮВАННЯ ПОВІТРЯ ЧИСТИХ ПРИМІЩЕНЬ
}

\begin{abstract}
У статті презентована інноваційна математична дослідниџька модель центральної прямотечійної системи кондииіювання повітря чистого приміщення з метою комп'ютерного оичнювання ї̈ ексергетичної ефективності залежно від різних факторів, щчо впливають на ї̈ роботу. Завдяки иій моделі отримано залежність ексергетичного ККД вибраної системи кондиціювання від різниці температур внутрішнього і припливного повітря та параметрів зовнішнього повітря.
\end{abstract}

Ключові слова: Ексергетичний баланс - Системи кондиціювання повітря - Чисті приміщення - Ексергетична ефективність

\section{В.И. Лабай, Д.И. Гарасымм}

Национальный университет «Львовская политехника», ул. Ст. Бандеры, 12, Львов, 79013

\section{ИССЛЕДОВАНИЕ ЕКСЕРГЕТИЧЕСКОЙ ЕФФЕКТИВНОСТИ СИСТЕМ КОНДИЦИОНИ- РОВАНИЯ ВОЗДУХА ЧИСТЫХ ПОМЕЩЕНИЙ}

\begin{abstract}
В статье представлена инновачионная математическая исследовательская модель иентральной прямоточной системы кондиционирования воздуха чистого помещения с целью компьютерной очуенки ее эксергетической эффективности в зависимости от разных факторов, какие влияют на ее работу. Благодаря этой модели получено зависимость эксергетического КПД избранной системы кондиционирования от разности температур внутреннего и приточного воздуха и параметров наружного воздуха.
\end{abstract}

Ключевые слова: Эксергетический баланс - Системы кондиционирования воздуха - Чи стые помещения - Эксергетическая эффективность

\section{І. ВСТУП}

Сьогодні під час створення обладнання і процесів для забезпечення проведення певної технології питання економії паливно-енергетичних ресурсів має першорядне значення. Тому зараз ставиться питання про створення енерготехнологічних агрегатів і процесів, в яких би вимоги технології та енергетики не тільки органічно поєднувались, але й доповнювали одне одного.

У сучасних технологіях, пов'язаних з перетворенням енергіï, а саме у системах кондиціювання повітря, важливе місце займають обладнання і процеси, об'єктивна оцінка ступеня енергетичної досконалості яких може бути встановлена тільки на основі їх термодинамічного аналізу. Найпростішим методом термодинамічного аналізу є енергетичний, заснований на законі збереження енергії. Він дозволяє оцінити абсолютні і відносні втрати енергії, виявити обладнання і процеси 3 найбільшими втратами. Однак цей метод прирівнює один до одного цінності всіх видів енергії, зокрема і теплової, що невірно з позицій другого закону термодинаміки, оскільки будь-який вид енергії може повністю перетворюватись у теплову, зворотній же процес супроводжується неминучими втратами.

Під впливом цих вимог в останні десятиріччя був розроблений ексергетичний метод аналізу [6-
10]. Цей метод був обгрунтований у роботах Р.К. Клаузіуса, Дж.В. Гіббса, Ж. Гюі, А. Стодоли, Я. Шаргута та Р. Петели. Його основна ідея полягає у введенні поряд 3 загальним, фундаментальним поняттям енергії, додаткового показника - ексерzii, який дозволяє врахувати той факт, що енергія залежно від зовнішніх умов може мати різну цінність для практичного використання.

Розрахунки балансів і різних характеристик технічних систем, зокрема систем кондиціювання повітря, 3 врахуванням ексергії дає можливість найпростіше і наглядніше вирішувати безліч наукових і технічних задач. Вони допомагають вилучити часті помилки, які зустрічаються і пов'язані 3 ігноруванням якісного боку перетворень.

Особливістю центральної прямотечійної системи кондиціювання повітря є те, що вихідна речовина, яка піддається обробці в ній, - це зовнішнє повітря, параметри якого можуть бути різними як за температурою так і за відносною вологістю (відповідно, вологовмістом і питомою ентальпією). У результаті роботи системи кондиціювання повітря набуває необхідні температуру і вологість як припливне повітря, так і повітря всередині приміщення. У системах кондиціювання повітря зовнішнім середовищем служить зовнішне повітря, параметри якого можуть бути різними залежно від місця і часу. Тому як навколишне середовище прийняте зовнішне повітря - як його суха частина, так і во- 
дяна пара, яка $є$ у повітрі. Зменшення затрат енергії, споживаної системами кондиціювання повітря (СКП), диктує необхідність їх оптимізації, що найповніше може бути досягнуто на основі ексергетичного аналізу, який враховує не тільки кількість, але й якість затраченої енергії [7, 8, 11-14, 16, 18, 19].

\section{II. ОПИСАННЯ ОБ'СКТУ АНАЛІЗУ ТА ІННОВАЦЙНОЇ ДОСЛІДНИЦЬКОЇ МОДЕЛІ}

Метою кондиціювання повітря є підтримання у деякому обмеженому просторі (у даному випадку у чистому приміщенні) певних параметрів повітря. Звичайно регулюванню підлягає температуpa $t_{\text {в }}$ і відносна вологість $\varphi_{\text {в }}$ повітря, а у чистих приміщеннях це ще й концентрація пилинок $x_{\mathrm{B}} \mathrm{y}$ повітрі [1-5].

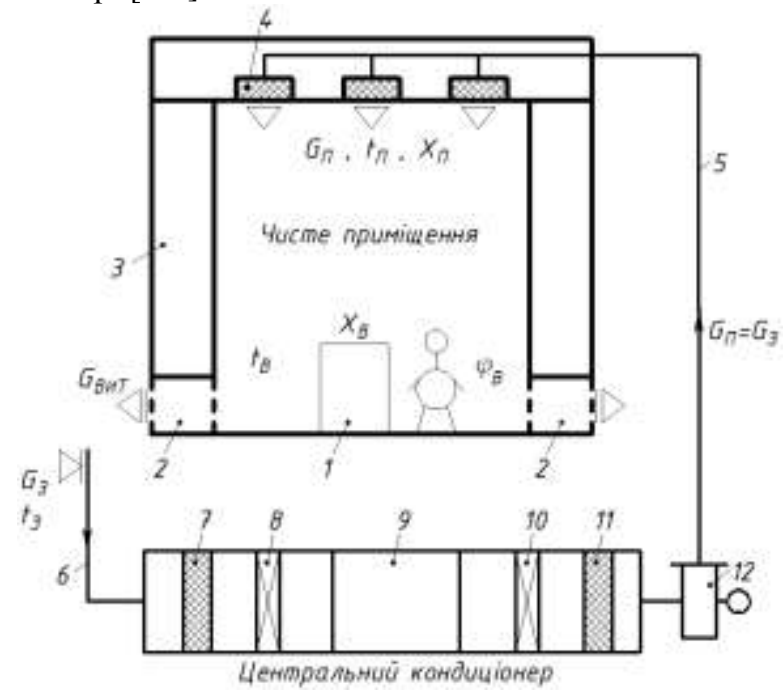

Рисунок 1 - Принциипова схема изентральної прямотечійної системи кондиціювання повітря чистого примішення: 1 - технологічне об-

ладнання, 2 - витяжні канали, 3 - илюзові приміщення, 4-фільтри припливного повітря у приміщення, 5 - припливний повітропровід, 6 - повітрозабірна шахта, 7 - фільтр зовнішнього повітря, 8 - повітронагрівник I підігрівання, 9 - камера зрошення,

10 - повітронагрівник II підігрівання,

11 - фільтр припливного повітря у кондиціонері, 12 - вентиляторний агрегат

Як приклад можна розглянути центральну прямотечійну СКП чистого приміщення, схематично зображену на рисунку 1 . Робота такої системи залежить від домінуючих у навколишньому (зовнішньому) середовищі умов, тобто від температури і вологовмісту повітря зовнішнього середовища. Повітря з навколишнього середовища через повітрозабірну шахту 6 забирається центральним кондиціонером, очищається у фільтрі зовнішнього повітря 7, далі проходить через повітронагрівник I підігрівання 8, охолоджується та осушується за політропою у камері зрошення 9, підігрівається у повітронагрівнику II підігрівання 10, а відтак вен- тиляторним агрегатом 12 подається у чисте приміщення через фільтр припливного повітря 11 у центральному кондиціонері, припливні повітропроводи 5 та фільтри припливного повітря 4 на вході у приміщення.

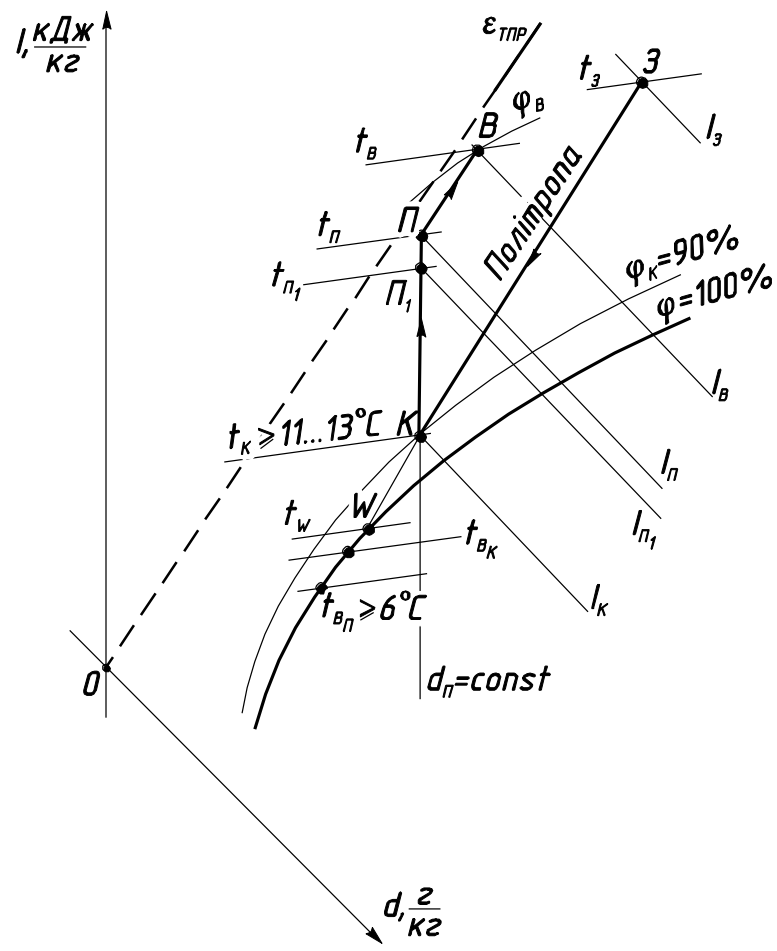

Рисунок 2 - Зображення процесів зміни стану вологого повітря у прямотечійній СКП в ТПР на I-d-діаграмі: $3 \boldsymbol{K}$ - процес політропного оброблення (охолодження та осушування) повітря $G_{\text {к.зр }}=G_{\text {П }}$ у камері зрошення;

$\boldsymbol{K \Pi}_{\boldsymbol{1}}$ - процес нагрівання повітря $G_{\Pi}$ у повітронагрівнику II підігрівання;

$\boldsymbol{\Pi}_{\boldsymbol{1}} \boldsymbol{\Pi}$ - підігрівання повітря $G_{\Pi}$ на $1{ }^{\circ} \mathrm{C} \mathrm{у} \mathrm{вен-}$ тиляторі та припливному повітропроводі; ПВ - процес асиміляиії тепло- і вологонадлишків 6 чистому приміщенні припливним повітрям $G_{\Pi}$

\section{з кондииіонера}

Розглянемо роботу даної СКП у ТПР, коли вологовміст $d_{\mathrm{B}}<d_{3}$ і температура $t_{\mathrm{B}}<t_{3}$. На рисунку 2 наведена у системі координат $I, d$ послідовність зміни параметрів повітря, яке проходить через різне обладнання центральної прямотечійної системи кондиціювання повітря чистого приміщення у ТПР. У дослідженнях прийнято масову продуктивність СКП, пораховану за кількістю пилинок, $G=10000$ кг/год, параметри зовнішнього повітря змінювались у межах $t_{3}=26$ $42^{\circ} \mathrm{C} ; d_{3}=9,3-15,9$ г/кг (відповідно, питома ентальпія $I_{3}=49,8-83,2$ кДж/кг; відносна вологість $\varphi_{3}=27-54 \%$ ), барометричний тиск $p_{3}=1010$ гПа; параметри внутрішнього повітря відповідно $-t_{\mathrm{B}}=$ $23-30{ }^{\circ} \mathrm{C} ; \varphi_{\mathrm{в}}=50 \%$ (відповідно, $d_{\mathrm{B}}=8,8-13,4$ г/кг; 
$I_{\mathrm{B}}=45,5-64,4$ кДж/кг); різниця температур між внутрішнім і припливним повітрям залежно від теплонадлишків у чистому приміщенні, а також температури зовнішнього повітря $\Delta t_{\Pi}=t_{\mathrm{B}}-t_{\Pi}=$ 1,5-6,0 ${ }^{\circ} \mathrm{C}$; кутовий коефіцієнт процесу асиміляції тепло- і вологонадлишків у чистому приміщенні припливним повітрям 3 кондиціонера $\varepsilon=9946-$ 16858 кДж/кг; температура води (холодоносія) для камери зрошення: початкова $t_{\mathrm{B}_{\Pi}}=7,0-14,9^{\circ} \mathrm{C}$; кінцева $t_{\mathrm{B}_{\mathrm{K}}}=9,8-17,3^{\circ} \mathrm{C}$; температура теплоносія (води) для повітронагрівника II підігрівання: початкова $t_{\text {гар }}=70^{\circ} \mathrm{C}$; кінцева $t_{3 \mathrm{~B}}=42^{\circ} \mathrm{C}$.

Послідовність змін, які відбуваються 3 вологим повітрям, що проходить через різне обладнання системи кондиціювання повітря, наведені на рисунку 2. Побудова на I-d - діаграмі виконана згідно 3 [11]. Параметри повітря у характерних точках процесу (рисунок 2) встановлювались за прийнятими значеннями параметрів для зовнішнього повітря та підраховувались на запропонованій математичній моделі за відомими аналітичними залежностями для вологого повітря.

Витрату холоду на оброблення повітря у камері зрошення (холодопродуктивність камери зрошення) у ТПР визначали за формулою:

$$
Q_{\mathrm{x}}=G_{\Pi} \cdot\left(I_{3}-I_{\mathrm{\kappa}}\right) \times 0,278, \mathrm{BT},
$$

а витрату теплоти на II підігрівання повітря у ТПР за такою формулою:

$$
Q_{2}=G_{\Pi} \cdot\left(I_{\Pi_{1}}-I_{\kappa}\right) \times 0,278, \text { Вт, }
$$

де $I_{3}, I_{\kappa}$, i $I_{\Pi_{1}}$-питома ентальпія повітря у відповідних точках процесів зміни стану вологого повітря у прямотечійній СКП в ТПР на $I-d-$ діаграмі (таблиця 1), кДж/кг.

Завданням даної роботи було створення інноваційної математичної дослідницької моделі центральної прямотечійної системи кондиціювання повітря чистого приміщення з метою комп'ютерного оцінювання іiі енергоефективності на основі ексергетичного ККД залежно від різних факторів, що впливають на іiі роботу. В цій моделі складались матеріальний, тепловий (енергетичний) та ексергетичний баланси даної системи, які враховували всі можливі варіанти її роботи в реальних умовах.

Для раціональної оцінки досконалості вказаної СКП користувались поняттям ексергетичного ККД, який визначався як відношення приросту ексергії повітря у кондиціонованому примі-

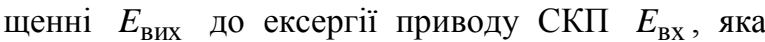
витрачалась на підтримання процесу [6-10, 12, 13, 15-20]:

$$
\eta_{\mathrm{e}}=\frac{E_{\mathrm{Bux}}}{E_{\mathrm{BX}}}
$$

Ексергетичний ККД, який характеризує ефективність роботи центральної прямотечійної систе- ми кондиціювання чистого приміщення у ТПР, визначали за формулою:

$$
\eta_{\text {екс }}=\frac{\Delta E_{\Pi \mathrm{B}}}{\Delta E_{\text {к.зр }}+\Delta E_{\text {нагр }}+N_{\mathrm{c} \Pi}^{\mathrm{X} . \mathrm{B}}+N_{\mathrm{c} \Pi}^{\text {.. B }}+N_{\mathrm{c} \Pi}^{\mathrm{Be} H \mathrm{HT}}+N_{\mathrm{c} \Pi}^{\mathrm{XM}}},
$$

де $\Delta E_{\text {пв }}=E_{\Pi}-E_{\text {в }}-$ зменшення ексергії кондиціонованого повітря у чистому приміщенні, Вт; $E_{\text {п }}$ i $E_{\text {в }}$ - відповідно, ексергія припливного і внутрішнього повітря у чистому приміщенні, Вт; $\Delta E_{\text {к.зр }}=E_{\mathrm{B}_{\mathrm{K}}}-E_{\mathrm{B}_{\text {п }}}-$ зміна ексергії води у камері зрошення (відповідно, зростання ексергії повітря у камері зрошення), Вт; $E_{\mathrm{B}_{\Pi}}$ і $E_{\mathrm{B}_{\mathrm{K}}}-$ відповідно, ексергія води у камері зрошення за її початкової та кінцевої температури, Вт; $\Delta E_{\text {нагр }}=E_{\text {гар }}-E_{\text {звор }}-$ зміна ексергії теплоносія (гарячої води) у повітронагрівнику II підігрівання (відповідно, зменшення ексергії повітря у повітронагрівнику II підігрівання), Вт; $E_{\text {гар }}$ і $E_{\text {звор }}$ - відповідно, ексергія теплоносія у подавальному і зворотному патрубках повітронагрівника II підігрівання, Вт; $N_{\mathrm{cп}}^{\mathrm{x.в}}-$ споживана потужність насосом холодної води для камери зрошення, Вт; $N_{\text {сп }}^{\text {г.в }}-$ споживана потужність насосом гарячої води для повітронагрівника II підігрівання, Вт; $N_{\text {сп }}^{\text {вент }}-$ споживана потужність двигуном вентилятора прийнятого центрального кондиціонера, Вт; $N_{\text {сп }}^{\mathrm{XM}}$ - споживана потужність холодильною машиною для центрального кондиціонера, Вт.

Величини, що входять у формулу (4), визначали так:

$$
\Delta E_{\Pi \mathrm{B}}=G_{\Pi} \cdot\left(e_{\Pi}-e_{\mathrm{B}}\right) \times 0,278, \text { Вт, }
$$

де $e_{\Pi}$ i $e_{\mathrm{B}}-$ відповідно, питома ексергія припливного і внутрішнього повітря у чистому приміщенні (таблиця 1), кДж/кг;

$$
\Delta E_{\text {к.зр }}=G_{\text {к.зр }} \cdot\left(e_{\mathrm{\kappa}}-e_{3}\right) \times 0,278, \text { Вт, }
$$

де $e_{3}$ і $e_{\mathrm{K}}-$ відповідно, питома ексергія зовнішнього повітря та охолодженого і осушеного у камері зрошення повітря (таблиця 1), кДж/кг;

$$
\Delta E_{\text {нагр }}=G_{\Pi} \cdot\left(e_{\mathrm{\kappa}}-e_{\Pi_{1}}\right) \times 0,278, \mathrm{BT},
$$

де $e_{\Pi_{1}}$ - питома ексергія нагрітого у повітронагрівнику II підігрівання повітря (таблиця 1), кДж/кг.

Якщо необхідно знати питому ексергію води за певної абсолютної температури $T_{\text {в }}$, то ії можна визначити за такою формулою:

$$
e_{\mathrm{B}}=c_{\mathrm{B}} \cdot\left(T_{\mathrm{B}}-T_{0}-T_{0} \cdot \ln \frac{T_{\mathrm{B}}}{T_{0}}\right), \text { кДж/кг, }
$$

де $c_{\mathrm{B}}=4.19$ кДж/(кг $\left.\mathrm{K}\right)-$ питома теплоємність води (за сталого тиску).

За потреби зміну ексергії у тепловому процесі можна визначити за такою формулою: 


$$
\Delta E=Q \cdot\left(1-\frac{T_{0}}{\bar{T}}\right), \mathrm{B},
$$

де $Q$ - тепловий потік, який має місце у тепловому процесі, Вт; $\bar{T}=273+0.5\left(t_{1}+t_{2}\right)$ - абсолютна середня температура у тепловому процесі, $\mathrm{K} ; t_{1}$ i $t_{2}$ - відповідно, початкова і кінцева температура у тепловому процесі, ${ }^{\circ} \mathrm{C}$.

Споживану потужність електродвигуна вентилятора для транспортування повітря визначали за формулою:

$$
N_{\text {сп }}^{\text {вент }}=N_{\text {вст }}^{\text {вент }} \cdot \eta_{\text {вент }}, \text { Вт, }
$$

де $N_{\mathrm{Bc}}^{\text {вент }}-$ встановлена потужність двигуна вентилятора прийнятого центрального кондиціонера, Вт; $\eta_{\text {вент }}$ - ККД вентилятора. Аналогічно визначали $N_{\mathrm{c} \text {. }}^{\text {х.в }}$ і $N_{\text {сп }}^{\text {г.в }}$.

Приймаючи коефіцієнт енергетичного класу холодильної машини E.E.R. $=2,8$, визначали іiі споживану потужність за формулою:

$$
N_{\mathrm{c} \Pi}^{\mathrm{XM}}=\frac{Q_{\mathrm{x}}}{E . E . R .}, \text { Вт. }
$$

Значення питомих ентальпій вологого повітря підраховувались так.

Питому ексергію вологого повітря у певних точках процесів, які характеризують роботу прямотечійної центральної СКП, визначали за такими формулами:

$$
e=e_{\phi}+e_{\mathrm{x}}, \text { кДж/кг, }
$$

де $e_{\phi}$ i $e_{\mathrm{x}}-$ відповідно, питома фізична і хімічна ексергія по відношенню до параметрів зовнішнього повітря (навколишнього середовища);

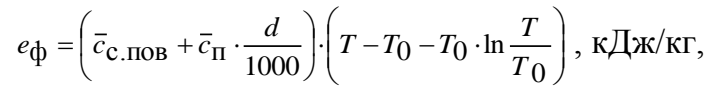

$\bar{c}_{\text {с.пов }}=1,005$ кДж/(кг·К) і $\bar{c}_{\Pi}=1,86$ кДж/(кг·К) відповідно, середня питома теплоємність (за сталого тиску) сухого повітря і водяної пари;

$T_{0}$ і $T$ - відповідно, абсолютна температура зовнішнього повітря (навколишнього середовища) і повітря у певній точці процесу, К $(273+t=T)$;

$$
e_{\mathrm{X}}=T_{0} \cdot\left[\begin{array}{l}
\left(R_{\mathrm{c} . \text { пов }}+R_{\Pi} \cdot \frac{d}{1000}\right) \cdot \ln \frac{622+d_{0}}{622+d}+ \\
+R_{\Pi} \cdot \frac{d}{1000} \cdot \ln \frac{d}{d_{0}}
\end{array}\right], \text { КДж/кГ, }
$$

$R_{\text {с.пов }}=0,287$ кДж/(кг·К) i $R_{\text {П }}=0,462$ кДж/(кг $\left.\cdot \mathrm{K}\right)$ - відповідно, газова стала сухого повітря і водяної пари;

$d_{0}$ і $d$ - відповідно, вологовміст зовнішнього повітря (навколишнього середовища) і повітря у певних точках процесу, г/кг.

Результати розрахунків питомої ексергії вологого повітря у певних точках процесів, які характеризують роботу прямотечійної центральної СКП, зводимо у таблицю 1.

Варто відзначити, що нами не були враховані втрати ексергії, пов'язані з втратою аеродинамічного тиску потоку повітря, які є порівняно незначними і ними можна знехтувати, а також невраховані втрати у навколишнє середовище, окрім цього прийнято, що процес зволоження у камері зрошення відбувається за політропою. Параметри, які характеризують стан повітря у всіх точках процесів для даної СКП, зведені в таблицю 1.

Таблиця 1 - Параметри точок, які характеризують стан вологого повітря під час роботи СКП

\begin{tabular}{|l|l|l|l|l|l|}
\hline $\begin{array}{l}\text { Точки } \\
I-d-\text { діаграмі }\end{array}$ & $\begin{array}{l}\text { Температура } \\
t,{ }^{\circ} \mathrm{C}\end{array}$ & $\begin{array}{l}\text { Питома } \\
\text { ентальпія } \\
I, \text { кДж/кг }\end{array}$ & $\begin{array}{l}\text { Вологовміст } \\
d, \text { г/кг }\end{array}$ & $\begin{array}{l}\text { Відносна } \\
\text { вологість } \\
\varphi, \%\end{array}$ & $\begin{array}{l}\text { Питома } \\
\text { ексергія } \\
e, \text { кДж/кг }\end{array}$ \\
\hline $\mathbf{3 ( \mathbf { O } )}$ & $26-42$ & $49,8-83,2$ & $9,3-15,9$ & $27-54$ & $0,0-0,0$ \\
\hline $\mathbf{B}$ & $23-30$ & $45,5-64,4$ & $8,8-13,4$ & $50-50$ & $0,0173-0,2707$ \\
\hline $\mathbf{\Pi}$ & $21,5-24,0$ & $43,5-57,3$ & $8,6-13,0$ & $54-69$ & $0,0385-0,5904$ \\
\hline $\mathbf{\Pi}_{\mathbf{1}}$ & $20,5-23,0$ & $42,4-56,2$ & $8,6-13,0$ & $57-74$ & $0,0559-0,6542$ \\
\hline $\mathbf{K}$ & $13,3-19,7$ & $35,1-52,8$ & $8,6-13,0$ & $90-90$ & $0,2870-0,8925$ \\
\hline
\end{tabular}

\section{III. РЕЗУЛЬТАТИ ДОСЛІДНИЦЬКОЇ РОБОТИ}

Підставляючи отримані розрахунками значення величин у формулу (4), розраховували значення ексергетичного ККД $\eta_{\mathrm{e}}$ для вказаної СКП залежно від зовнішніх температурних умов, а саме: температури $t_{3}$ і вологовмісту $d_{3}$ зовнішнього повітря, та подавали їх у вигляді залежностей ексергетичного ККД $\eta_{\mathrm{e}}$ від різниці температур внутрішнього і припливного повітря $\Delta t_{\text {п }}$ та вологовмісту $d_{3}$ зовнішнього повітря на рисунку 3 і на цій основі робили аналіз.

Аналізуючи отримані дані досліджень на рисунку 3, можна дійти таких висновків. Загальне зростання різниці температур внутрішнього і припливного повітря $\Delta t_{\text {п }}$ від 1,5 до $6,0^{\circ} \mathrm{C}$, тобто в 4 рази, за загального зростання у 3 ряду вологовмісту зовнішнього повітря $d_{3}$ від 10,3 до 14,9 г/кг, тобто в 1,45 рази, призводить до значного зростання значення ексергетичного ККД $\eta_{\text {e }}$ від 0,26 до 2,30, 
тобто в 8,85 рази або на 785\%. Варто також зауважити (рисунок 3), що за різниці температур внутрішнього і припливного повітря $\Delta t_{\Pi}=6,0^{\circ} \mathrm{C}$ зростання вологовмісту зовнішнього повітря $d_{3}$ від 13,9 до 15,9 г/кг, тобто в 1,14 рази, призводить до незначного зменшення значення ексергетичного ККД $\eta_{\mathrm{e}}$ від 2,44 до 2,18 , тобто в 1,12 рази або на $12 \%$. А значить за певної різниці температур внутрішнього і припливного повітря $\Delta t_{\text {п }}$ за необхідності можна знехтувати впливом вологовмісту зовнішнього повітря $d_{3}$. Тому вибрану систему кондиціювання повітря бажано використовувати за вищої різниці температур внутрішнього і припливного повітря, а саме, наприклад $\Delta t_{\Pi}=6,0^{\circ} \mathrm{C}$ (відповідно температури зовнішнього повітря $t_{3}=42^{\circ} \mathrm{C}$ ), що дасть можливість отримати найвищий ексергетичний ККД $\eta_{\mathrm{e}}$, а значить отримати економічно найвигідніший варіант використання вибраної системи кондиціювання повітря.

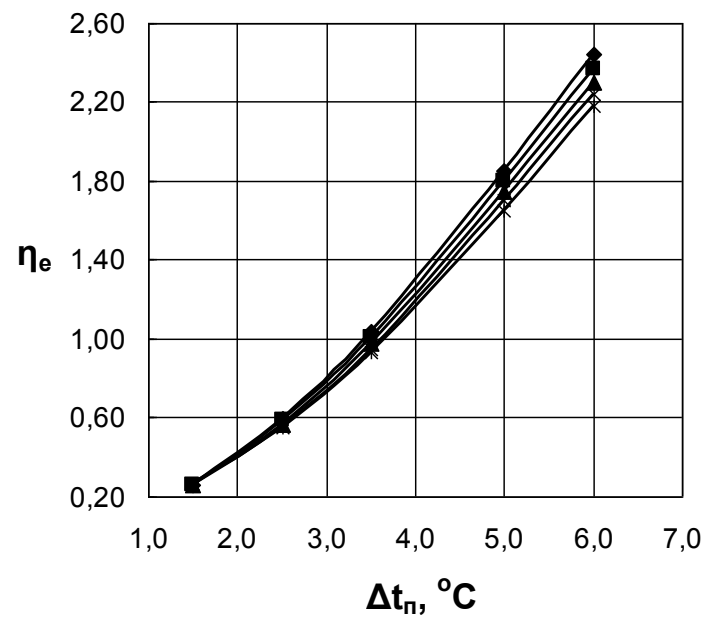

Рисунок 3 - Залежність ексергетичного ККД $\eta_{\mathrm{e}}$ центральної прямотечійної системи кондиціювання повітря чистого приміщення від різниці температур внутрішнього і припливного повітря $\Delta t_{\text {п }} i$ вологовмісту зовнішнього повітря: 1 ряд - $d_{3}=9,3-13,9$ г/кг; 2 ряд

$$
\text { - 9,8-14,4; } 3 \text { ряд А - 10,3-14,9; }
$$$$
4 \text { ряд } \mathrm{x}-10,8-15,4 ; 5 \text { ряд } \mathrm{x}-11,3-15,9
$$

Варто звернути увагу (рисунок 3), що за різниці температур внутрішнього і припливного повітря $\Delta t_{\text {п }}$ від 1,5 до $3,5^{\circ} \mathrm{C}$ маємо один закон зміни ексергетичного ККД $\eta_{\mathrm{e}}$, а за різниці температур внутрішнього і припливного повітря $\Delta t_{\text {п }}$ від 3,5 до $6,0^{\circ} \mathrm{C}$ - інший. Це пояснюється тим, що температура внутрішнього повітря у чистому приміщенні приймається по-різному до температури зовнішнього повітря $t_{3}=30^{\circ} \mathrm{C}$ і вище неї. Тому ці зміни розглянемо окремо.
Отже, зростання різниці температур внутрішнього і припливного повітря $\Delta t_{\text {п }}$ від 1,5 до $3,5^{\circ} \mathrm{C}$, тобто в 2,33 рази, за загального зростання у 3 ряду вологовмісту зовнішнього повітря $d_{3}$ від 10,3 до 12,7 г/кг, тобто в 1,23 рази, призводить до значного зростання значення ексергетичного ККД $\eta_{\mathrm{e}}$ від 0,26 до 0,98, тобто в 3,77 рази або на 277\%. Варто також зауважити (рисунок 3), що за різниці температур внутрішнього і припливного повітря $\Delta t_{\text {п }}$ $=3,5^{\circ} \mathrm{C}$ зростання вологовмісту зовнішнього повітря $d_{3}$ від 11,7 до 13,7 г/кг, тобто в 1,17 рази, призводить до незначного зменшення значення ексергетичного ККД $\eta_{\mathrm{e}}$ від 1,04 до 0,93 , тобто в 1,12 рази або на $12 \%$, чим за необхідності можна знехтувати. Разом $з$ тим середня швидкість зміни ексергетичного ККД $\eta_{\mathrm{e}}$ на цій початковій ділянці $\Delta \eta_{\mathrm{e}} / \Delta\left(\Delta t_{\Pi}\right)$ становить $0,361 /{ }^{\circ} \mathrm{C}$.

Відповідно зростання різниці температур внутрішнього і припливного повітря $\Delta t_{\text {п }}$ від 3,5 до $6,0^{\circ} \mathrm{C}$, тобто в 1,714 рази, за загального зростання у 3 ряду вологовмісту зовнішнього повітря $d_{3}$ від 12,7 до 14,9 г/кг, тобто в 1,17 рази, призводить до значного зростання значення ексергетичного ККД $\eta_{\mathrm{e}}$ від 0,98 до 2,30, тобто в 2,35 рази або на $135 \%$. В той самий час середня швидкість зміни ексергетичного ККД $\eta_{\mathrm{e}}$ на цій ділянці $\Delta \eta_{\mathrm{e}} / \Delta\left(\Delta t_{\Pi}\right)$ становить $0,5281 /{ }^{\circ} \mathrm{C}$, що в 1,47 рази більше, тобто на $47 \%$, ніж на початковій ділянці.

Залежності, наведені на рисунку 3, отримані нами у вигляді аналітичних формул для різниці температур внутрішнього і припливного повітря $\Delta t_{\Pi}=1,5-3,5^{\circ} \mathrm{C}$ :

$$
\begin{aligned}
\eta_{\mathrm{e}}= & 0,7166 \cdot \Delta t_{\Pi}+0,0433 \cdot d_{3}- \\
& -0,0289 \cdot \Delta t_{\Pi} \cdot d_{3}-0,8149
\end{aligned}
$$

а для $\Delta t_{\Pi}=3,5-6,0^{\circ} \mathrm{C}$ :

$$
\begin{aligned}
\eta_{\mathrm{e}}= & 1,0199 \cdot \Delta t_{\Pi}+0,0433 \cdot d_{3}- \\
& -0,0289 \cdot \Delta t_{\Pi} \cdot d_{3}-1,8765
\end{aligned}
$$

Максимальна похибка розрахунків за формулою (15) становить $14,0 \%$ і за формулою (16) $7,3 \%$.

Якщо знехтувати за даної різниці температур внутрішнього і припливного повітря $\Delta t_{\text {п }}$ залежністю ексергетичного ККД $\eta_{\text {e }}$ від вологовмісту зовнішнього повітря $d_{3}$, то результати, отримані на рисунку 3 , можна подати так:

$$
\bar{\eta}_{\mathrm{e}}=0,1371 \cdot\left(\Delta t_{\Pi}\right)^{1,5753},
$$

де $\bar{\eta}_{\mathrm{e}}$ - середнє значення ексергетичного ККД.

Максимальна похибка розрахунків у цьому випадку за формулою (17) становить 6,5\%.

Значить ексергетичний аналіз центральної прямотечійної системи кондиціювання повітря чистого приміщення виконаний на створеній авторами інноваційній математичній дослідницькій моделі дав можливість грунтовно оцінити залеж- 
ність ексергетичного ККД $\eta_{\mathrm{e}}$ цієї системи від різниці температур внутрішнього і припливного повітря $\Delta t_{\Pi}$ і вологовмісту $d_{3}$ зовнішнього повітря.

\section{IV. ВИСНОВКИ}

Описана інноваційна математична дослідницька модель центральної прямотечійної системи кондиціювання повітря чистого приміщення, що дає можливість комп'ютерного оцінювання іiї енергоефективності на основі ексергетичного ККД залежно від різних факторів, що впливають на іiі роботу. Наведено залежність ексергетичного ККД $\eta_{\mathrm{e}}$ центральної прямотечійної системи кондиціювання повітря чистого приміщення від різниці температур внутрішнього і припливного повітря $\Delta t_{\text {п }}$ і вологовмісту $d_{3}$ зовнішнього повітря. Показано, що вибрану систему кондиціювання повітря бажано використовувати за вищої різниці температур внутрішнього і припливного повітря, а саме, наприклад $\Delta t_{\Pi}=6,0^{\circ} \mathrm{C}$ (відповідно температури зовнішнього повітря $t_{3}=42^{\circ} \mathrm{C}$ ), що дасть можливість отримати найвищий ексергетичний ККД $\eta_{\mathrm{e}}$, a значить отримати економічно найвигідніший варіант використання вибраної системи кондиціювання повітря.

\section{ЛІТЕРАТУРА}

1. Федотов А.Е. Чистые помещения. Второе изд., перераб. и доп. - М.: АСИНКОМ, 2003. - 576 с.

2. Хаякава И. Чистые помещения. Пер. с японск. - М.: Мир, 1990. - 456 с.

3. Уайт В. Технология чистых помещений. Основы проектирования, испытаний и эксплуатации. М.: Клинрум, 2002. - 304 с.

4. Уайт В. Проектирование чистых помещений. Пер. с англ. - М.: Клинрум, 2004. - 360 с.

5. ГОСТ ИСО 14644-1. Чистые помещения и связанные с ними контролируемые среды. Часть 1. Классификация чистоты воздуха.

6. Соколов Е.Я. Энергетические основы трансформации тепла и процессов охлаждения: учеб. пособие для вузов.- 2-е изд., перераб. / Е.Я. Соколов, В.М. Бродянский. - М.: Энергоиздат, 1981. $320 \mathrm{c}$.

7. Шаргут Я. Эксергия / Я. Шаргут, Р. Петела. М.: Энергия, 1968. - 280 с.

8. Эксергетические расчеты технических систем: справ. пособие / [В.М. Бродянский, Г.П. Верхивкер, Я.Я. Карчев и др.]; под ред. А.А. Долинского, В.М. Бродянского; Ин-т технической теплофизики АН УССР. - Киев: Наук. думка, 1991. $-360 \mathrm{c}$.

9. Бродянский В.М. Эксергетический метод термодинамического анализа / В.М. Бродянский. М.: Энергия, 1973. - 296 с.

10.Бэр Г.Д. Техническая термодинамика / Г.Д. Бэр. - М.: Мир, 1977. - 518 с.

11. Богословский В.Н. Кондиционирование воздуха и холодоснабжение: Учебник для вузов / В.Н. Богословский, О.Я. Кокорин, Л.В. Петров. Стройиздат, 1985. - 367 с.

12. Прохоров В.И. Метод вычисления эксергии потока влажного воздуха / В.И. Прохоров, С.М. Шилклопер // Холодильная техника. - 1981, № 9. C. 37-41.

13. Шилклопер С.М. Эксергетический анализ систем обеспечения микроклимата и энергоснабжения / С.М. Шилклопер, С.И. Жадин // Строительство и архитектура. Сер. 9. - 1982, вып. 4. C. $18-27$.

14. СНиП 2.04.05-86. Отопление, вентиляция и кондиционирование. - М.: ЦИТП Госстроя СССР, 1987. -64 c.

15.Янтовский Е.И. Потоки энергии и эксергии / Е.И. Янтовский. - М.: Наука, 1988. - 144 с.

16. Bes T. Egzergia w procesach ogrzewania, klimatyzacji i suszenia / T. Bes // Energetyka Przemysłowa. - 1962. 10, № 11. - S. 388-392.

17. Labaj Włodzimierz. Efektywność egzergetyczna autonomicznych klimatyzatorów miejscowych / Włodzimierz Łabaj, Oksana Omelczuk // XIV Konferencja ciepłowników „Perspektywy rozwoju ciepłownictwa". Materiały konferencyjne. - Solina: Politechnika Rzeszowska, 26-28 września 2002 r. S. 137-144.

18. Лабай Володимир. Ексергетична ефективність центральних кондиціонерів / Володимир Лабай, Тарас Іванух // V Konferencja naukowa RzeszowskoLwowsko-Koszycka „Aktualne problemy budownictwa i inżynierii środowiska”. Zeszyty naukowe Politechniki Rzeszowskiej «Budownictwo i inżynieria środowiska». - Z. 32, część 2: Inżynieria Środowiska. - Rzeszów: Politechnika Rzeszowska, 25-26 września 2000 r. - S. 229-235.

19. Лабай В.Й. Оцінка ефективності систем кондиціонування повітря методом ексергетичного аналізу / В.Й. Лабай, Т.В. Іванух // Вісник Держ. унів. «Львівська політехніка». - 2000. - № 404: Теплоенергетика. Інженерія довкілля. Автоматизація. - С. 66-70.

20. Лабай В.Й. Енергетичний та ексергетичний баланси барабанної сушарки для цукру-піску / В.Й. Лабай, Я.М. Ханик // Науковий вісник: зб. наук.-техн. праць. - Львів: УкрДЛТУ, 2004. Вип. 14.7. - С. 340-346. 
V.Y. Labay, D.I. Harasym

Lviv Polytechnic National University, 12 St. Bandery str., Lviv, 79013

\section{RESEARCH OF EXERGY EFFICIENCY OF AIR CONDITIONING SYSTEMS FOR CLEANROOMS}

In modern technologies, which are related to energy transformation, namely in the air conditioning systems, important place is occupied by objects creation and improvement of which requires the use of innovation thermodynamics. Classic apparatus of this science is often insufficient to solve new tasks; it is necessary not only to its further development, but its combination with the elements of a systematic approach and energetics.

Innovation mathematical research model of the central straight flow air conditioning system for cleanroom in order to computer's estimation its energy effective by virtue of exergetic output-input ratio depending on different factors, which have influence on its work, was described in this article. The dependence of exergetic output-input ratio for chosen air conditioning system $\eta_{\mathrm{e}}$ on temperature difference between the inside and the supplied air $\Delta t_{\mathrm{S}}=t_{\mathrm{in}}-t_{\mathrm{S}}$, depending on excess heat in the cleanroom, and moisture content $d_{\text {out }}$ of outdoor air was defined thanks to this model. It is shown that the chosen air conditioning system should be preferably used at higher temperature difference between the inside and the supplied air, namely, for example $\Delta t_{\mathrm{S}}=6,0^{\circ} \mathrm{C}$ ( respectively outdoor air temperature $t_{\mathrm{out}}=42^{\circ} \mathrm{C}$ ), that will give the opportunity to gain the highest exergetic output-input ratio $\eta_{\mathrm{e}}$, which means to gain the most advantageous economical variant of exploitation of chosen air conditioning system.

Keywords: Exergy balance - Air conditioning systems - Cleanrooms -Exergy efficiency

\section{REFERENCES}

1. Fedotov A.E. 2003. Chistye pomeshcheniia. Vtoroe izd., pererab. i dop. - Moskva: ASINKOM, 2003. - 576 (in Russian)

2. Hayakava I. 1990. Chistye pomeshcheniia. Per. s iaponsk. - Moskva: Mir. - 456 (in Russian).

3. Whyte W. 2002. Tekhnologiia chistykh pomeshchenii. Osnovy proektirovaniia, ispytanii i ekspluatatsii. - Moskva: Klinrum. - 304 (in Russian).

4. Whyte W. 2004. Proektirovanie chistykh pomeshchenii. Per. s angl. - Moskva: Klinrum. - 360 (in Russian).

5. GOST ISO 14644-1. Chistye pomeshcheniia i sviazannye s nimi kontroliruemye sredy. Chast' 1. Klassifikatsiia chistoty vozdukha (in Russian).

6. Sokolov E.Ia. 1981. Energeticheskie osnovy transformatsii tepla i protsessov okhlazhde-niia: ucheb. posobie dlia vuzov. - 2-e izd., pererab. / E.Ia. Sokolov, V.M. Brodianskii. - Moskva: Energoizdat. - 320 (in Russian).

7. Shargut Ia. 1968. Eksergiia / Ia. Shargut, R. Petela. - Moskva: Energiia. - 280 (in Russian).

8. Eksergeticheskie raschety tekhnicheskikh sistem. 1991: sprav. posobie / [V.M. Brodianskii, G.P. Verhivker, Ia.Ia. Karchev i dr.]; pod red. A.A. Dolinskogo, V.M. Brodianskogo; In-t tekhnicheskoi teplofiziki AN USSR. - Kiev: Nauk. dumka. - 360.

9. Brodianskii V.M. 1973. Eksergeticheskii metod termodinamicheskogo analiza / V.M. Brodianskii. Moskva: Energiia. - 296 (in Russian).

10.Ber G.D. 1977. Tekhnicheskaia termodinamika / G.D. Ber. - Moskva: Mir. - 518 (in Russian).

11.Bogoslovskii V.N. 1985. Konditsionirovanie vozdukha i kholodosnabzhenie: Uchebnik dlia vuzov / V.N. Bogoslovskii, O.Ia. Kokorin, L.V. Petrov. Stroiizdat. - 367 (in Russian).

12.Prokhorov V.I. 1981. Metod vychisleniia eksergii potoka vlazhnogo vozdukha / V.I. Prokhorov, S.M. Shilkloper // Kholodil'naia tekhnika. - № 9. 37-41 (in Russian).
13.Shilkloper S.M. 1982. Eksergeticheskii analiz sistem obespecheniia mikroklimata i energosnabzheniia / S.M. Shilkloper, S.I. Zhadin // Stroitel'stvo i arkhitektura. Ser. 9. - Vyp. 4. - 18-27 (in Russian).

14.SNiP 2.04.05-86. 1987. Otoplenie, ventiliatsiia i konditsionirovanie. - Moskva: TsITP Gosstroia SSSR. -64 (in Russian).

15.Iantovskii E.I. 1988. Potoki energii i eksergii / E.I. Iantovskii. - Moskva: Nauka. - 144 (in Russian).

16.Bes T. 1962. Egzergia $w$ procesach ogrzewania, klimatyzacji i suszenia / T. Bes // Energetyka Przemysłowa. - 10, № 11. - 388-392 (in Polish).

17.Labaj Włodzimierz. 2002. Efektywność egzergetyczna autonomicznych klimatyzatorów miejscowych / Włodzimierz Łabaj, Oksana Omelczuk // XIV Konferencja ciepłowników „Perspektywy rozwoju ciepłownictwa". Materiały konferencyjne. - Solina: Politechnika Rzeszowska, 26-28 września. - 137-144 (in Ukrainian).

18.Labai Volodymyr. 2000. Eksergetychna efektyvnist' tsentral'nykh kondytsioneriv / Volodymyr Labai, Taras Ivanukh // V Konferencja naukowa Rzeszowsko-Lwowsko-Koszycka „Aktualne problemy budownictwa i inżynierii środowiska". Zeszyty naukowe Politechniki Rzeszowskiej «Budownictwo i inżynieria środowiska». - Z. 32, część 2: Inżynieria Środowiska. - Rzeszów: Politechnika Rzeszowska, 25-26 września. - 229-235 (in Ukrainian).

19.Labai V.I. 2000. Otsinka efektyvnosti system kondytsionuvannia povitria metodom eksergetychnogo analizu / V.I. Labai, T.V. Ivanukh // Visnyk Derzh. univ. «L'vivs'ka politekhnika». - № 404: Teploenergetyka. Inzheneriia dovkillia. Avtomatyzatsiia. - 66-70 (in Ukrainian).

20.Labai V.I. 2004. Energetychnyi ta eksergetychnyi balansy barabannoi susharky dlia tsukru-pisku / V.I. Labai, Ia.M. Khanyk // Naukovyi visnyk: zb. nauk.tekhn. prats'. - L'viv: UkrDLTU. - Vyp. 14.7. - 340346 (in Ukrainian).

Отримана в редакції 04.06.2014, прийнята до друку 06.06.2014 


\section{ВІДОМОСТІ ПРО АВТОРІВ}

Лабай Володимир Йосифович - професор кафедри “Теплогазопостачання і вентиляція” Національного університету “Львівська політехніка", д.т.н., проф.

Службова адреса: 79013, м. Львів, вул. Ст. Бандери, 12, тел. (+380-32) 258-27-05.

Домашня адреса: 79007, м. Львів, вул. Огієнка, 20/34, тел. моб. (+38) 050-55-98-698, (+38) 096-20-02-220; e-mail: wlabay@i.ua.

Гарасим Дмитро Ігорович - аспірант кафедри “Теплогазопостачання і вентиляція” Національного університету “Львівська політехніка".

Службова адреса: 79013, м. Львів, вул. Ст. Бандери, 12, тел. (+380-32) 258-27-05.

Домашня адреса: 79044, м. Львів, вул. Квітнева, 1/21, тел. (+380-32) 237-01-48, тел. моб. (+38) 06783-12-506. 